\title{
Isolation and characterization of Bacillus thuringiensis strains from different grain habitats in Turkey
}

\author{
Özgür Apaydin ${ }^{1}$, A. Fazil Yenidünya ${ }^{2}$, Şebnem Harsa ${ }^{3}$ and Hatice Güneş ${ }^{2, *}$ \\ ${ }^{1}$ Biotechnology Program, İmir Institute of Technology, İzir TR-35430, Turkey \\ ${ }^{2}$ Department of Biology, İzmir Institute of Technology, Izmir TR-35430, Turkey \\ ${ }^{3}$ Department of Food Engineering Izmir Institute of Technology, İmir TR-35430, Turkey \\ *Author for correspondence: Tel.: +90-232-750-7544,Fax: +90-232-750-7509, E-mail: haticegunes@iyte.edu.tr
}

Received 8 March 2004; accepted 17 July 2004

Keywords: Bacillus thuringiensis, cry genes, grain habitats, isolation, plasmid, PFGE profiles

\begin{abstract}
Summary
Bacillus thuringiensis (Bt) is a gram-positive, spore-forming bacterium and it produces insecticidal crystal (cry) proteins during sporulation. Because the genetic diversity and toxic potential of Bt strains differ from region to region, strains have been collected and characterized all over the world. The aim of this study is to isolate Bt strains in grain-related habitats in Turkey and to characterize them on the basis of crystal morphology, cry gene content, and chromosomal and plasmid DNA profiles. Four approaches were taken: analysis with phase contrast (PC) microscopy, polymerase chain reaction (PCR), pulsed field gel electrophoresis (PFGE) and plasmid isolation. Ninety-six samples were collected from Central Anatolia and the Aegean region. Bt was isolated from 61 of 96 samples $(63.5 \%)$ and $500 \mathrm{Bt}$-like colonies were obtained. One hundred and sixty three of the colonies were identified as Bt based on cry protein formation using PC microscopy. Among the examined colonies, the overall proportion identified (as Bt index) was 0.33 . We found that 103 isolates were positive for the five different $c r y$ genes (cry1, cry2, cry3, cry4 and cry9) examined with PCR. In addition, plasmid profiling of 37 cry gene-positive isolates indicated that the $15 \mathrm{~kb}$ plasmid band was present in all isolates; however, 11 of 37 isolates had more than one plasmid band at different sizes. Finally, chromosomal DNA profiling by PFGE gave rise to different DNA patterns for isolates containing the same cry gene which suggests a high level of diversity among the Bt strains isolated.
\end{abstract}

\section{Introduction}

Bacillus thuringiensis (Bt) is a gram-positive, facultative anaerobe and spore-forming bacterium. It produces different insecticidal toxic proteins in parasporal crystals during the stationary phase of its growth cycle (Rowe et al. 1987). The genes coding for cry proteins are mostly carried on plasmids ranging from 3-4 to $150 \mathrm{Mda}$ (Gonzales \& Carlton 1980; Aronson 2002). Up to now, many cry protein genes have been cloned, sequenced and named cry genes. Over 100 cry gene sequences are organized into 32 groups and different subgroups based on nucleotide similarities and range of host specificity (Crickmore et al. 1998; Bravo et al. 1998).

Insecticidal activity of $\mathrm{Bt}$ depends mostly on cry proteins and varies with insect type. Natural isolates of $\mathrm{Bt}$ have been used as biological pesticides against different insect orders such as Lepidoptera, Diptera, Coleoptera, Hymenoptera, Homoptera and Acari (Cannon 1993; Fieltson et al. 1992). In addition, some strains of $\mathrm{Bt}$ have been found to be toxic to nematodes and protozoa (Feitelson et al. 1992; Edwards et al. 1988). The lack of mammalian toxicity of cry proteins has resulted in an increase in the use of $\mathrm{Bt}$ as an insecticide and intensified the search for new strains with different toxic activities.

It has been reported that $\mathrm{Bt}$ can be present in many different habitats such as soil, stored product dust, insect cadavers, grains, agricultural soils, olive tree related-habitats, different plant and aquatic environments (Martin \& Travers 1989; Meadows et al. 1992; Ben-Dov et al. 1997; Theunis et al. 1998; Bravo et al. 1998; Bel et al. 1997; Mizuki et al. 1999; Iriarte et al. 2000). Bt strains show genetic diversity with different toxic potential mostly due to plasmid exchange between strains (Thomas et al. 2001). In fact, each habitat may contain a novel Bt strain awaiting discovery which has a toxic effect on a target insect group. Therefore, Bt strains have been collected from different environments and characterized to evaluate their toxic potential against various insect orders (Chak et al. 1994; Theunis et al. 1998; Bravo et al. 1998; Forsyth \& Logan 2000; Uribe et al. 2003). Different methods are used for the 
characterization of $\mathrm{Bt}$ isolates such as polymerase chain reaction (PCR), southern blotting, serotyping and bioassay; however, PCR is the most widely used, efficient and rapid technique for screening of a large number of isolates (Juarez-Perez et al. 1997; Porcar \& Juarez-Perez 2002).

Because the use of Bt products as an alternative to chemical insecticides is increasing rapidly, many research centres have focused on isolation of the native strains in order to establish Bt strain collection worldwide. Therefore, the purpose of this study is to initiate the establishment of a native Bt strain collection from different regions of Turkey and to determine its diversity. We isolated and characterized $103 \mathrm{Bt}$ isolates from grain-related habitats of Central Anatolia and the Aegean regions of Turkey based on crystal formation, cry gene content, and plasmid and chromosomal DNA profiles.

\section{Materials and methods}

\section{Sample collection}

Soil, grain, stored product dust, straw, insect cadavers and various residues were collected from grain silos, crop fields, farms, caves, haylofts where Bt preparation have not been applied, in central Anatolia (Ereğli/ Konya, Takale/Karaman) and the Aegean region (Nikfer/Denizli, Bozbük/Söke) as shown in Table 1. Samples were taken from the places not exposed to sunlight or at $5 \mathrm{~cm}$ depth from the surface and were placed into plastic

Table 1. Distribution of Bacillus thuringiensis based on sample types and location ${ }^{\mathrm{a}}$.

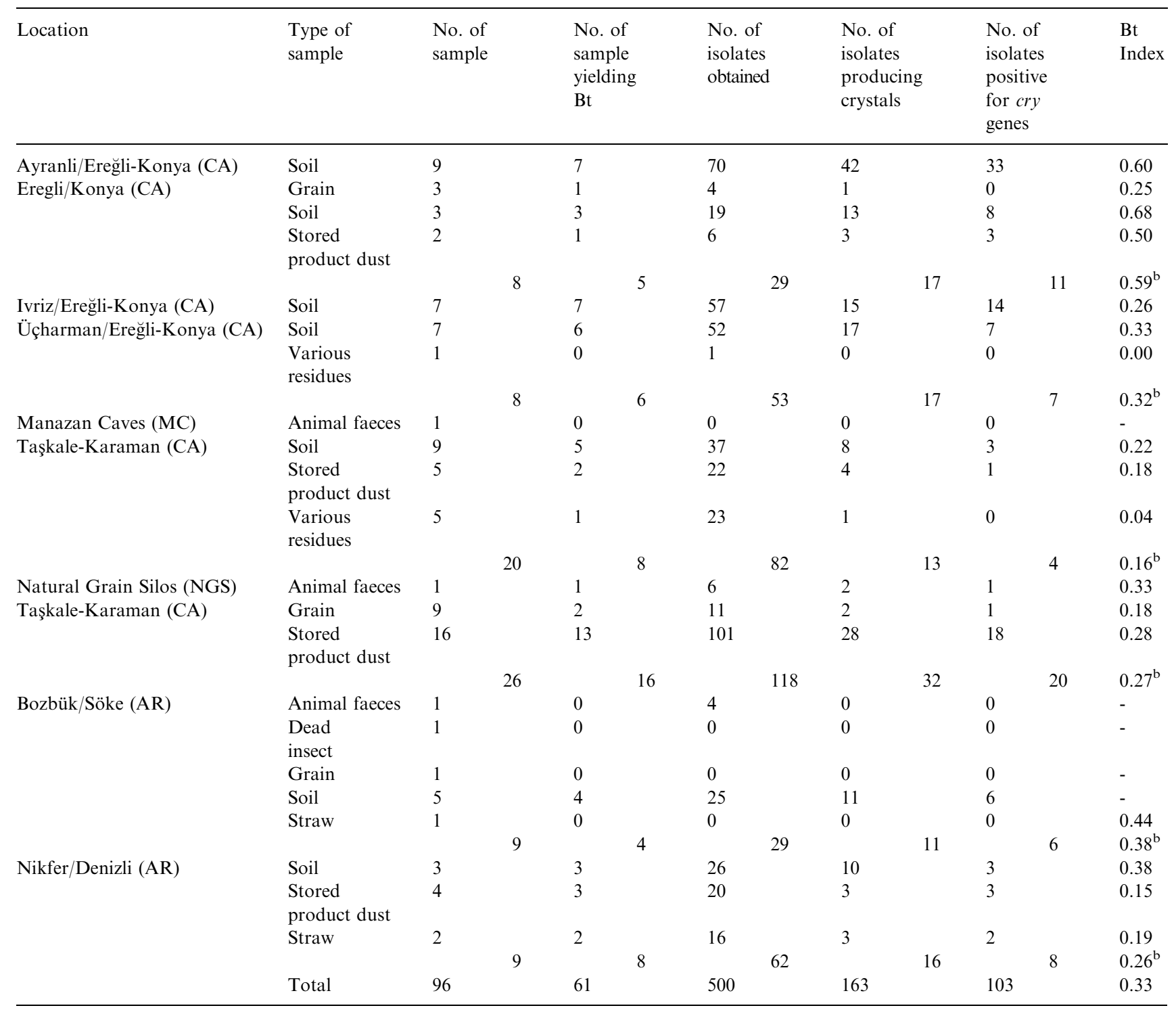

${ }^{\mathrm{a}}$ Isolates were examined with PC microscope for crystal formation and cry gene content of crystal positive isolates was screened by PCR. CA: Central Anatolia, AR: Aegean Region. Bt index is the ratio of Bt isolates producing crystal to all isolates in each sample group.

${ }^{\mathrm{b}}$ Indicates the total $\mathrm{Bt}$ index in each geographical location. 
bags aseptically. All samples were stored at $4{ }^{\circ} \mathrm{C}$ until processed.

\section{Bacterial strains}

B. thuringiensis subsp. kurstaki (HD1), B. thuringiensis subsp. Aizawai (HD133), B. thuringiensis subsp. kumamotoensis (HD867), B. thuringiensis biovar. tenebrionis (tenebrionis), B. thuringiensis biovar. israelensis (HD500) were kindly supplied by Dr Daniel R. Zeigler from the Bacillus Genetic Stock Center (Ohio, USA) and used as reference strains.

\section{Bacillus thuringiensis isolation and crystal morphology analysis}

Bt strains were isolated based on the acetate selection method described by Travers et al. (1987). Briefly, $0.25 \mathrm{~g}$ of the environmental sample were suspended in $10 \mathrm{ml}$ nutrient broth (Applichem) medium containing $0.25 \mathrm{M}$ sodium acetate and left for microbial growth at $37^{\circ} \mathrm{C}$ overnight. Heat treatment was then applied for 5 min at $80^{\circ} \mathrm{C}$ to kill vegetative cells. After that, they were plated on nutrient agar plates and allowed to grow overnight at $37^{\circ} \mathrm{C}$. Bt-like colonies which are usually described as cream-coloured and have the appearance of a fried egg on the plates (Travers et al. 1987) were labelled and subcultured. Subculturing from an individual colony was repeated three times to obtain a pure culture. Finally, each pure culture was grown on T3 agar plates and colonies dispersed in sterile distilled water were examined with a PC microscope for crystal production and morphology. Duplicate stock samples were prepared from each of the isolates in $25 \%$ glycerol and kept at $-80{ }^{\circ} \mathrm{C}$.

\section{Cry gene identification}

Polymerase chain reaction (PCR) was used to identify cry gene content. All isolates producing crystal proteins were screened by five pairs of universal primers for the cry1, cry2, cry3, cry4 and cry9 genes described by Ben-Dov et al. (1997, 1999). DNA isolation was performed by the method of Bravo et al. (1998). Briefly, a loopful of cells from overnight Bt cultures was transferred into $0.2 \mathrm{ml}$ of water and suspended. After freezing at $-80{ }^{\circ} \mathrm{C}$ for $20 \mathrm{~min}$, they were transferred into boiling water for $10 \mathrm{~min}$. The cell lysate was centrifuged (Henttich, Micro 12-24 Eppendorf Model) for $10 \mathrm{~s}$ at $11,000 \times g$ and $15 \mu \mathrm{l}$ of supernatant were used as DNA template. PCR reactions were carried out in $50 \mu \mathrm{l}$ reaction volumes. DNA template was mixed with reaction buffer containing $200 \mu \mathrm{M}$ deoxynucleotide triphosphate mix, $0.5 \mu \mathrm{M}$ each primer (synthesized by Integrated DNA Technologies), $3 \mathrm{mM} \mathrm{MgCl}$ and $2 \mathrm{U}$ of Taq DNA polymerase (Fermentas). Amplifications were carried out in a DNA thermal cycler (Techne Progen, England). For all cry genes, an initial denaturation step was applied at $94{ }^{\circ} \mathrm{C}$ for $1 \mathrm{~min}$ and followed by denaturation at $94{ }^{\circ} \mathrm{C}$ for $1 \mathrm{~min}$, annealing at $54{ }^{\circ} \mathrm{C}$ (for cry 1 ) and $60{ }^{\circ} \mathrm{C}$ (for cry 2 , cry 3 , cry 4 and cry9) for 1 min, then extension at $72{ }^{\circ} \mathrm{C}$ for $1 \mathrm{~min}$. Thirty-five cycles were carried out for the amplification of cry gene fragments. Finally, an extra extension step was applied at $72{ }^{\circ} \mathrm{C}$ for $10 \mathrm{~min}$. After amplifications, $10 \mu \mathrm{l}$ of each PCR product were electrophoresed on $1 \%$ agaroseethidium bromide (Sigma) gel in TAE buffer $(0.04 \mathrm{M}$ Tris-Acetate, $0.001 \mathrm{M}$ EDTA [pH 8]) at $95 \mathrm{~V}$ for $40 \mathrm{~min}$. Gels were visualized in a gel documentation system (Vilber Lourmat, France).

\section{Plasmid profiling}

Plasmid isolation was performed with minor modifications of the method described by O'Sullivan \& Klaenhammer (1993). Bacterial cultures were grown on nutrient agar plates overnight and transferred into eppendorf tubes by scraping gently with the help of sterile distilled water. After pelleting the cells, they were resuspended in $200 \mu \mathrm{l}$ of a solution containing $25 \%$ sucrose and $30 \mathrm{mg}$ lysozyme/ml (Applichem) and incubated at $37{ }^{\circ} \mathrm{C}$ for $15 \mathrm{~min}$. The sample was mixed with $400 \mu$ alkaline SDS solution (3\% SDS, $0.2 \mathrm{~N} \mathrm{NaOH})$ and incubated for $7 \mathrm{~min}$ at room temperature. Then $300 \mu$ ice-cold $3 \mathrm{M}$ sodium acetate ( $\mathrm{pH} 4.8)$ was added, mixed and centrifuged at $11,000 \times g$ for $20 \mathrm{~min}\left(4^{\circ} \mathrm{C}\right)$. Supernatants were transferred into new eppendorf tubes, mixed with $650 \mu \mathrm{l}$ of isopropanol (Sigma) and centrifuged again at $11,000 \times g$ for $20 \mathrm{~min}\left(4^{\circ} \mathrm{C}\right)$. After discarding all liquid, pellets were resuspended in $320 \mu \mathrm{l}$ sterile distilled water. They were mixed with $200 \mu \mathrm{l}$ $7.5 \mathrm{M}$ ammonium acetate containing $0.5 \mathrm{mg} / \mathrm{ml}$ ethidium bromide and $400 \mu \mathrm{l} \mathrm{phenol/chloroform,} \mathrm{then} \mathrm{cen-}$ trifuged at $11,000 \times g$ for $10 \mathrm{~min}$, at room temperature. Upper phases were transferred into new eppendorf tubes and mixed with $1 \mathrm{ml}$ ethanol at $-20^{\circ} \mathrm{C}$. After centrifugation at $11,000 \times g$ for $20 \mathrm{~min}\left(4^{\circ} \mathrm{C}\right)$, pellets were washed with $70 \%$ ethanol. All liquid was discarded and the pellets were dissolved in $25 \mu$ TER (TE, $\mathrm{pH} 7.8$ and RNase, $0.1 \mathrm{mg} / \mathrm{ml}$ ). After incubation at $37^{\circ} \mathrm{C}$ for $20 \mathrm{~min}$, plasmid samples were electrophoresed in $0.8 \%$ agarose-ethidium bromide gel at $80 \mathrm{~V}$ for $3 \mathrm{~h}$ and visualized with the gel documentation system.

\section{PFGE analysis}

PFGE analysis was carried out according to Rivera \& Priest (2003) with some modifications. Bacterial strains were grown in $10 \mathrm{ml}$ nutrient broth overnight and cells were harvested by centrifugation at $4{ }^{\circ} \mathrm{C}$ for $2 \mathrm{~min}$ at $4500 \mathrm{rev} / \mathrm{min}$. Cells were washed with $500 \mu \mathrm{l}$ TE (50 mM Tris, $1 \mathrm{mM}$ EDTA, pH 8.0) and SE (10 mM $\mathrm{NaCl}, 30 \mathrm{mM}$ EDTA, pH 7.5) buffer, respectively. The cells were then resuspended in $50 \mu \mathrm{l} \mathrm{SE}$ buffer, mixed with $50 \mu \mathrm{l} 2 \%$ agarose (Low Melt) at $50{ }^{\circ} \mathrm{C}$, and dispensed into the slots of plug mould. The plugs were 
allowed to set at room temperature. The cells embedded into agarose were allowed to lyse in lysis buffer $(30 \mathrm{mM}$ Tris, $50 \mathrm{mM} \mathrm{NaCl}, 5 \mathrm{mM}$ EDTA, $\mathrm{pH} 8.0$ ) containing $2 \mathrm{mg} / \mathrm{ml}$ lysozyme at $37^{\circ} \mathrm{C}$ for $18 \mathrm{~h}$. Bacterial plugs were then washed three times with $5 \mathrm{ml}$ of buffer containing $20 \mathrm{mM}$ Tris, $50 \mathrm{mM}$ EDTA, pH 8.0. Proteins were digested with $2 \mathrm{ml}$ proteinase $\mathrm{K}$ solution $(0.5 \mathrm{mg}$ proteinase $\mathrm{K} / \mathrm{ml}$ and $0.1 \% \mathrm{~N}$-lauroylsarcosineEDTA, $50 \mathrm{mM}, \mathrm{pH} 8.0)$ at $50{ }^{\circ} \mathrm{C}$ overnight. Then plugs were washed twice with $5 \mathrm{ml}$ of buffer containing $20 \mathrm{mM}$ Tris, $50 \mathrm{mM}$ EDTA, $1 \mathrm{mM} \mathrm{NaCl}$, pH 8.0; once with buffer containing Tris, $50 \mathrm{mM}$ EDTA, $1 \mathrm{mM}$ PMSF, pH 8.0, and once with buffer containing $20 \mathrm{mM}$ Tris, $50 \mathrm{mM}$ EDTA, pH 8.0. After the plugs were equilibrated with $1 \mathrm{ml}$ restriction enzyme buffer, they were digested with $40 \mathrm{U}$ of SmaI (Fermentas) at $30{ }^{\circ} \mathrm{C}$ for $20 \mathrm{~h}$. Then the plugs were electrophoresed in $1 \%$ agarose in TBE buffer in a CHEF-DRII system at $14{ }^{\circ} \mathrm{C}$ for $40 \mathrm{~h}$ at $4 \mathrm{~V} / \mathrm{cm}$ with pulse times of $15 \mathrm{~s}$ rising to $60 \mathrm{~s}$. After staining the gel in ethidium bromide $(1 \mu \mathrm{l} / \mathrm{ml})$ for $45 \mathrm{~min}$ and destaining in distilled water for $1 \mathrm{~h}$, DNA profiles were recorded in a gel documentation system (Vilber Lourmat, France).

\section{Results}

Bacillus thuringiensis distribution shown by sample types and locations

In total 96 samples, 78 from Central Anatolia region and 18 from the Aegean region were examined in this study (Table 1). Sample types consist of 43 soil, 27 stored product dust, 13 grain and 13 other samples including straw, animal faeces, various residues and an insect cadaver. After acetate selection, no microbial growth was observed in six grain samples and six other samples in different groups. According to colony morphology and PC microscopy analysis, Bt was isolated from 61 of the 96 samples which corresponds to $63.5 \%$ of the whole number of samples (Table 1). Five hundred isolates were obtained from these 61 samples. Bt index, reflecting the ratio of $\mathrm{Bt}$ colonies in total colonies isolated, was found to vary between 0.00 and 0.68 through origins with the average value of 0.33 (Table 1). Compared to all locations, Ereğli/Konya was the richest area for $\mathrm{Bt}$ occurrence with an $0.59 \mathrm{Bt}$ index.

\section{Crystal composition of the isolates}

Five hundred isolates were examined with the PC microscope for spore formation and crystal production (Figure 1). Among them, 163 isolates produced crystals (Table 1). Even though 99 other isolates had Bt-like spore and colony morphology, they did not show crystal formation. The remaining 238 isolates did not exhibit any morphological similarities to Bt nor did they produce crystals.

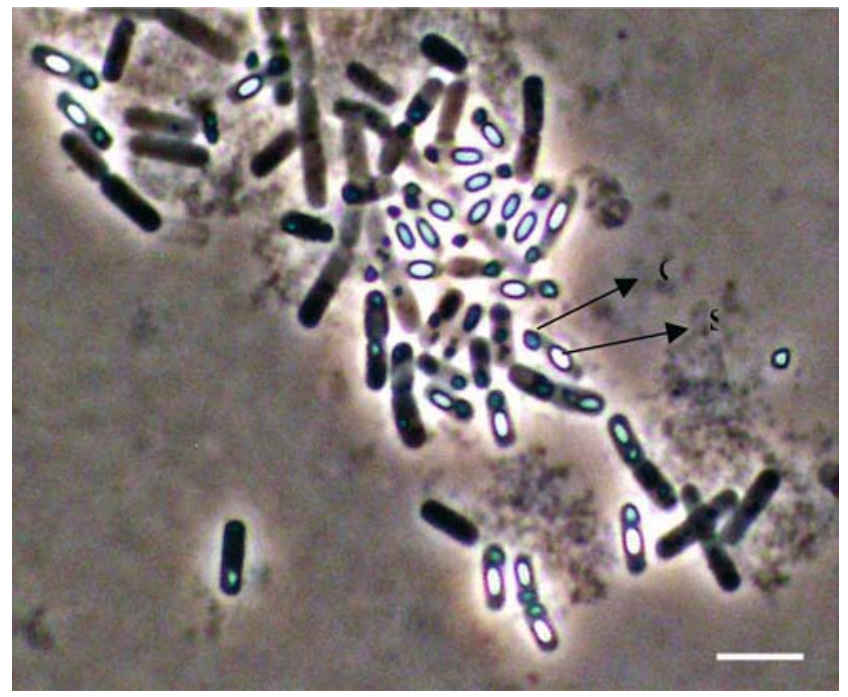

Figure 1. Photomicrography of a $\mathrm{Bt}$ isolate, $39 \mathrm{Ya}$. The $\mathrm{Bt}$ isolate was grown for $48 \mathrm{~h}$ and examined with the $\mathrm{PC}$ microscope for spore formation and crystal protein production. Some cells were lysed and spores and crystals released into the medium whereas the others were intact. Arrow $\mathrm{C}$ and $\mathrm{S}$ indicate crystal protein and spore, respectively. Bar represents $2.5 \mu \mathrm{m}$.

Crystal morphology of Bt can give information about target insect spectra (Maeda et al. 2000). Therefore, in order to determine the crystal morphology of each Bt isolate, all isolates were grown for $48 \mathrm{~h}$ and examined with the PC microscope. Five different crystal shapes were observed in 163 isolates. Although only one type of crystal morphology was observed in some isolates, more than one type of crystal morphology was present in others (Figure 2). Distribution of crystal shapes in 163 isolates was $36 \%$ spherical (S), $5 \%$ cubic (C), 9\% irregular pointed (IP), 2\% bipyramidal (B), 19\% cubic and spherical (C\&S), 22\% spherical and irregular pointed (S\&IP), $1 \%$ cubic and irregular pointed (C\&IP), 2\% irregular shaped (IS), and 6\% not defined (Figure 2).

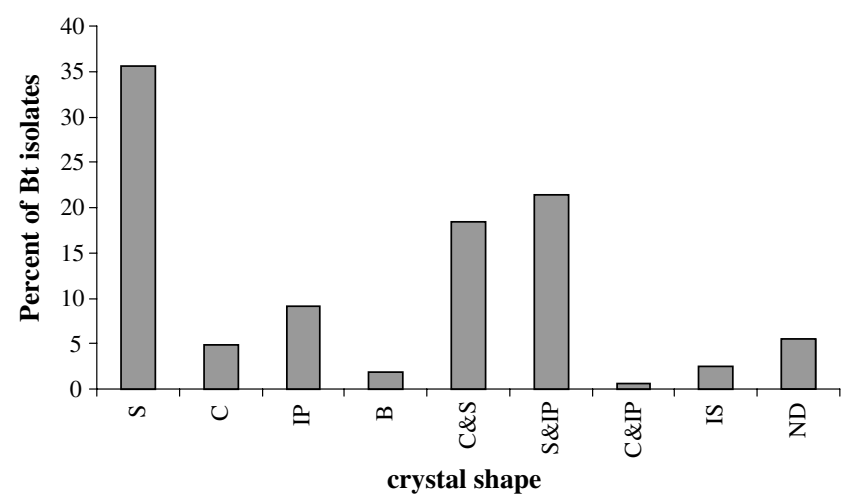

Figure 2. Crystal shape distribution of Bt isolates. After growing the isolates for $48 \mathrm{~h}$, crystal protein formation was observed using a PC microscope. Description of crystal shapes is: C: cubic, B: bipyramidal, S: spherical, IP: irregular pointed, IS: irregular shaped, ND: not defined. 


\section{Characterization of cry gene content of the isolates}

Because crystal proteins are encoded by cry genes and one Bt strain can contain more than one cry protein, the cry gene content of each isolate had to be determined. PCR reactions for each isolate were carried out with universal primers specific for cry 1, cry 2, cry3, cry4 and cry9 genes. One hundred and three of 163 isolates were positive for the cry genes examined. Some examples of PCR products amplified with different cry gene primers are shown in Figure 3. Even though most of the isolates gave only one DNA band with a specific cry gene primer, some of them showed two or three DNA bands with the same cry gene primer (Figure 3).

PCR analysis of each isolate with five different cry gene primers indicated that 63 of the isolates had only one type of cry gene; however, 40 of them contained more than one type of cry gene (Figure 4). The number of isolates carrying one type of $c r y$ gene are 17 for $c r y l$, 6 for $c r y 2,10$ for $c r y 3,7$ for $c r y 4$ and 21 for $c r y 9$. On the other hand, 28 isolates contained two different cry genes. In addition, 8 isolates were positive for 3 different cry genes and 4 isolates for 4 different cry genes (Figure 4).

No amplification of DNA template was observed for 60 isolates producing crystal protein indicating that they have cry genes different from the genes examined in this study.

\section{Plasmid and PFGE profiles of the isolates}

Bt has been known to have several circular/linear plasmids, and cry genes are generally found in these plasmids (Carson et al. 1996). Therefore, in the present study plasmids were isolated from 33 cry gene-positive isolates as well as four different Bt reference strains. A major plasmid band at $15 \mathrm{~kb}$ in size was obtained in all isolates (Figure 5). In addition, plasmid bands varying in length between 15 and $22 \mathrm{~kb}$ were observed in some of the isolates: cry2-positive (lanes 11, 12, 13, 14, 16), cry3-positive (lanes 18, 19), and cry9-positive (lanes 30, 31).

Pulsed field gel electrophoresis (PFGE) of chromosomal DNA digested with a restriction enzyme is an

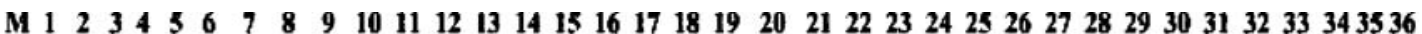

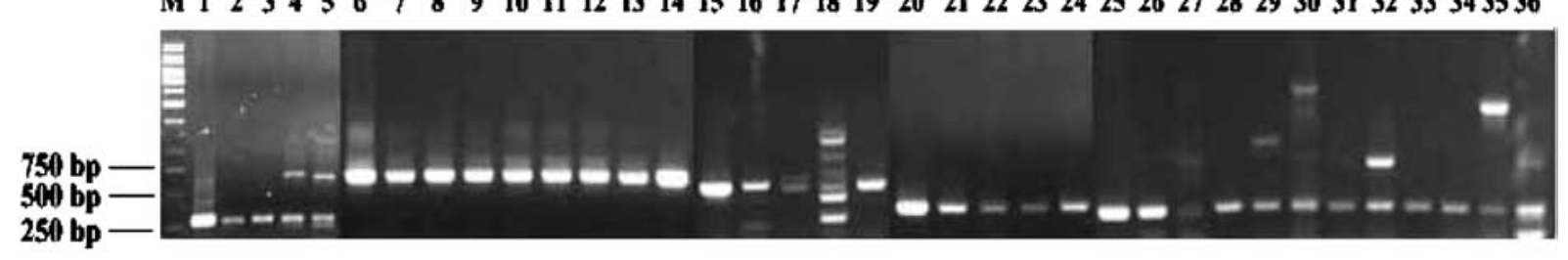

Figure 3. PCR analysis of crystal protein positive isolates. DNA template from each isolate was amplified with PCR in the presence of each cry gene primer. PCR products of some of the isolates are for cry1, lanes 1-5; cry2, lanes 6-14; cry3, lanes 15-19; cry4, lanes 20-24; cry9, lanes 25-36. Identity of isolates in each lane is LaneM: 1kb DNA MW marker; Lane1: Bacillus thuringiensis subsp. aizawai; Lane2: 39Yb; Lane3: 43Db; Lane4: 48Ra; Lane5: 71Na; Lane6: Bacillus thuringiensis subsp. kurstaki; Lane7: 18Fa; Lane8: 93Ha; Lane9: 93Da; Lane10: 93FFa; Lane11: 27Fb; Lane12: 19Rb; Lane13: 19Hb; Lane14: 85PPb; Lane15: Bacillus thuringiensis biovar. tenebrionis; Lane16: 21KB; Lane17: 71Lb; Lane18: 98Lb; Lane19: 86Db; Lane20: Bacillus thuringiensis biovar. israelensis; Lane21: 19Pb; Lane22: 2Ja; Lane23: 28Da; Lane24: 113Ya; Lane25: Bacillus thuringiensis subsp. aizawai; Lane26: 82YYb; Lane27: 36Ba; Lane28: 24Ca; Lane29: 25Ca; Lane30: 94YYb; Lane31: 24Nb; Lane32: 93Da; Lane33: 25Aa; Lane34: 29Fa; Lane35: 53Yb; Lane36: 62PPa.

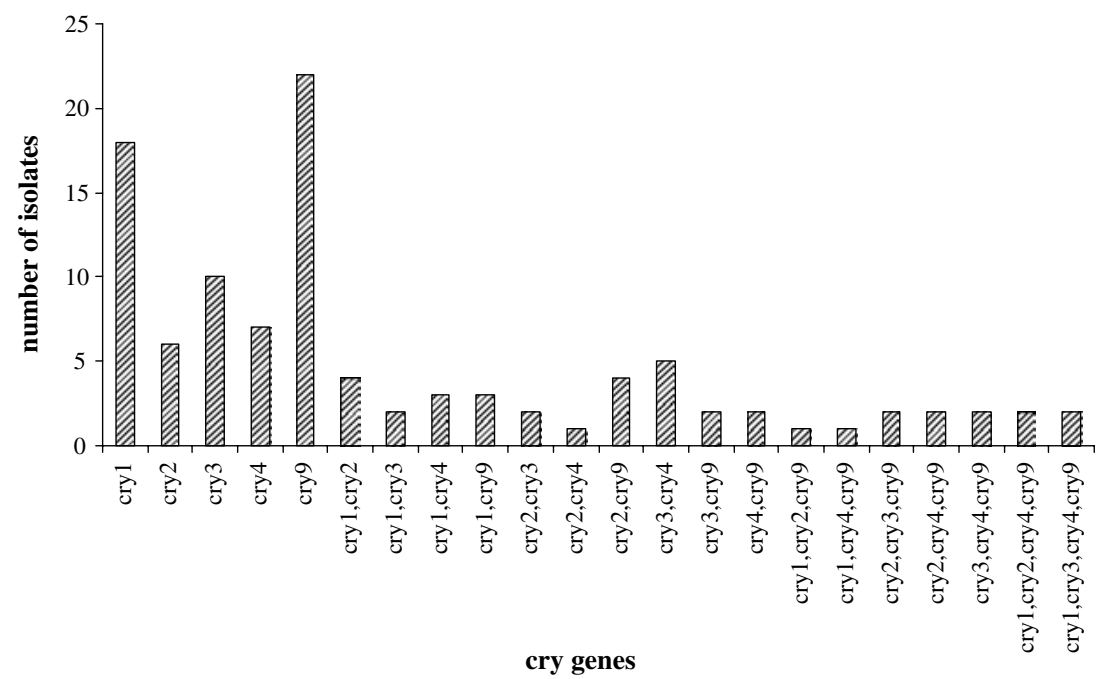

Figure 4. cry gene distribution of Bt isolates. Crystal protein-producing isolates were screened by PCR to find out their cry gene contents by using five primer pairs for cry1, cry2, cry3, cry4 and cry9. Figure shows number of isolates and their cry gene profiles. 


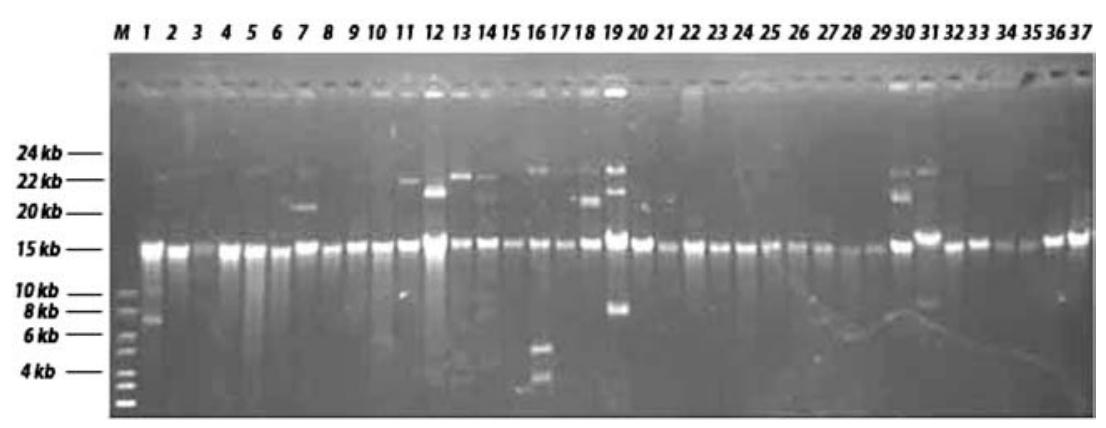

Figure 5. Plasmid patterns of Bt isolates. Plasmid DNA was prepared from 33 cry gene-positive isolates and subjected to electrophoresis in $0.8 \%$ agarose gel with ethidium bromide. Name of the isolate or reference strain in each lane is as follows: Lane M: $1 \mathrm{~kb}$ DNA Ladder; Lane1: Bacillus thuringiensis subsp. aizawai; Lane2: 48Ra; Lane3: 39Ya; Lane4: 39Yb; Lane5: 43Db; Lane6: 71Na; Lane7: 55Ka; Lane8: Bacillus thuringiensis subsp. kurstaki; Lane9: 18Fa; Lane10: 93FFa; Lane11: 93Ha; Lane12: 19Rb; Lane13: 27Fb; Lane14: 93Da; Lane15: 19Hb; Lane16: 85PPb; Lane17: Bacillus thuringiensis biovar. tenebrionis; Lane18: 71Lb; Lane19: 2Ja; Lane20: 98Lb; Lane21: 86Db; Lane22: Bacillus thuringiensis biovar. israelensis; Lane23: 19Pb; Lane24: 28Da; Lane25: 113Ya; Lane26: Bacillus thuringiensis subsp. aizawai; Lane27: 82Yb; Lane28: 24Nb; Lane29: 25Aa; Lane30: 25Ca; Lane31: 36Ba; Lane32: 29Fa; Lane33: 93Da; Lane34: 94YYb; Lane35: 53Yb; Lane36: 24Ca; Lane37: 62PPa.

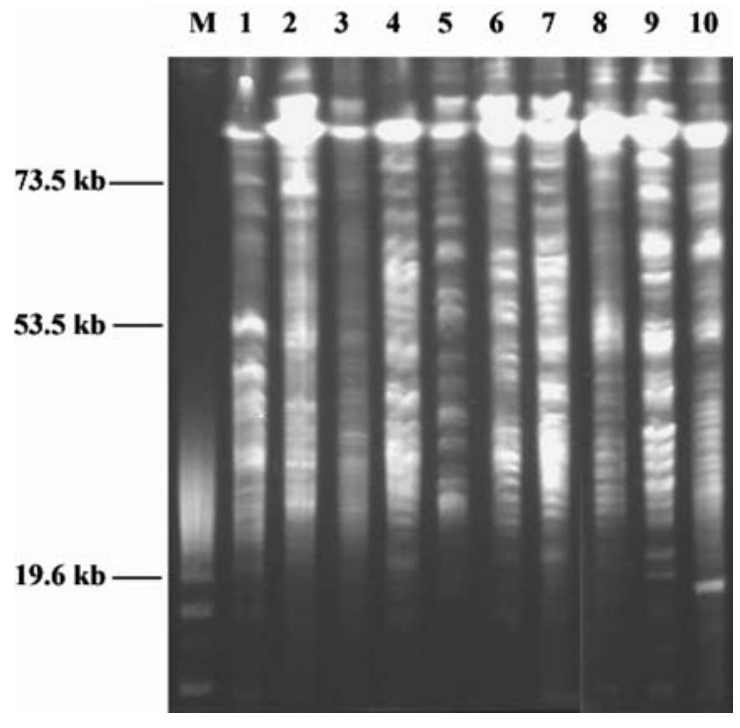

Figure 6. PFGE profiles of cry 9-positive isolates. PFGE analysis was carried out as described in Materials and Methods section. Identity of the isolate in each lane is as follows: LaneM: $5 \mathrm{~kb}$ DNA ladder; Lane1: 62PPa; Lane2: 24Ca; Lane3: 28Aa; Lane4: 53Yb; Lane5: 94YYb; Lane6: 93Da; Lane7: 29Fa; Lane8: 25Aa; Lane9: 82YYb; Lane10: Bacillus thuringiensis subsp. aizawai.

accurate typing method for bacteria (Tenover et al. 1995). In order to see if Bt isolates carrying the same cry gene show similar PFGE patterns, chromosomal DNA from 6 cry 1,8 cry 2, 5 cry 3,4 cry 4 and 11 cry 9 positive isolates was subjected to PFGE analysis. Even though there are some similarities among the PFGE patterns of the isolates (data not shown except for cry9), no identical patterns were obtained within each of the cry gene groups (Figure 6).

\section{Discussion}

In this study, Bt occurrence was examined in grainrelated habitats of Central Anatolia and in the Aegean region where no Bt products have been applied before.
Bt occurence in all soil samples collected from Konya was found to be relatively high compared to other soil samples (Table 1). Especially in İvriz, Bt was isolated from all of the samples. These places are crop fields and this suggests the abundant presence of $\mathrm{Bt}$ in agricultural lands. The percentage of samples yielding Bt from Nikfer was also high, $89 \%$. This is because the sampled haylofts had been used for 65 years. In addition, natural grain silos (NGS) have been used for grain storage for more than 500 years and the percent of samples yielding Bt was $62 \%$. In fact, Bt indexes of NGS and Nikfer are very similar with the values of 0.27 and 0.26 , respectively. This shows a similar degree of occurrence of Bt in two places with similar background.

The Bt index serves as a measurement of success in isolating Bt. After acetate selection for Bt isolation, no growth was observed in six of the grain samples. In all regions, the percentage of grain samples yielding $\mathrm{Bt}$ was relatively low in grain samples $(23 \%)$ when compared with those of soil $(81 \%)$, stored product dust $(70 \%)$ and straw $(67 \%)$ samples (Table 1). This indicates that grain is not as good a source as the others for Bt. An average Bt index was found to be 0.33 for all samples but the index changes according to sample types and origins (Table 1). The abundance of Bt was the highest in all soil samples, with a Bt index of 0.40 . It decreases to 0.26 in all stored dust product samples and to 0.20 in all grain and animal faeces. Unlike our study, Bravo et al. (1998) collected soil samples from cultivated fields in Mexico and obtained a Bt index of about 0.24 , nearly twofold lower than our index. However, Martin \& Travers (1989) found the highest $\mathrm{Bt}$ index as 0.85 in the soil samples collected from Asia, nearly twofold greater than ours. This may be related to climate and geographic conditions. In addition, Hongyu et al. (2000) and Bernhard et al. (1997) reported that $\mathrm{Bt}$ is more abundant in stored product environments than in soil. Taken together, these studies show that the level of Bt index changes from region to region and between types of samples. 
Because there is a relationship between toxic activity and crystal shape of Bt strains (Maeda et al. 2000), observation of crystal morphology by PC microscope can provide valuable information about toxic activity of $\mathrm{Bt}$ isolates. In fact, observation of crystal morphology is the first step for establishing Bt strain collection (Ohba \& Aizawa 1986; Bernhard et al. 1997). Therefore, when the crystal shape of the isolates was examined using a PC microscope, it was found that $42 \%$ of the isolates had more than one crystal shape; however, $58 \%$ of them had only one crystal shape (Figure 2). More definitive results about toxic activity of the isolates will be obtained from bioactivity assay of each isolate in the future study because a discrepancy exists between predicted cry gene type and its insecticidal activity (Shisa et al. 2002). For example, even though the cryl gene product is toxic against Lepidoptera, Shisa et al. have reported that the cryl gene product of native $\mathrm{Bt}$ strains was toxic to only Diptera.

In addition, it was observed that a $\mathrm{Bt}$ isolate was sometimes positive for two or more cry genes even though it had only one type of crystal morphology. This may be due to lack of expression of all different cry genes at protein level. Moreover, 99 isolates exhibited spore and colony morphology similar to that of $\mathrm{Bt}$ whereas no crystal formation was observed by PC microscope. On the other hand, when PCR analysis was performed for nine of them, seven isolates were positive for cry genes examined. This is also related to the absence of gene expression at the protein level. In fact, crystal protein synthesis in $\mathrm{Bt}$ is controlled by a variety of mechanisms at the transcriptional, post-transcriptional or post-translational levels (Agassie \& Lereclus, 1995).

PCR screening of 163 crystal-forming isolates indicated that 103 of them were positive with primers for the five different $c r y$ genes examined. The number of isolates containing the cry9 gene was the greatest (21) compared to that of isolates containing the cryl gene (17), cry 2 gene (7) and cry3 gene (10) and cry4 gene (8). However, Bravo et al. (1998) have found cryl genes the most frequent $(49.5 \%)$, then cry3 gene as highly abundant $(21.7 \%)$ and $\operatorname{cry} 9$ gene less abundant $(2.6 \%)$. These results show how different geographic regions affect diversity of cry gene content of Bt strains. In addition, it is probable that the remaining 60 isolates negative for the observed cry genes may contain different cry genes from the ones examined in this study because 32 different cry gene groups and many subgroups have been defined in the literature (Schnepf et al. 1998; Crickmore et al. 1998).

PFGE patterns of restriction enzyme-digested genomic DNA is known to be a useful technique to identify closely related bacterial isolates (Bygraves \& Maiden 1992; Tenover et al. 1995). A recent study by Rivera \& Priest (2003) has indicated that PFGE is a better technique than $\mathrm{H}$-serotyping for discriminative typing of Bt strains. In the present study, we carried out PFGE analysis in order to see if isolates carrying the same cry gene are identical. Although there were some similarities among PFGE patterns of the isolates (Figure 6), none of them were the same. Based on Rivera \& Priest (2003), if PFGE patterns differed by changes up to 3 bands and more than three bands, strains are described as closely related and unrelated, respectively. Therefore, our isolates carrying the cry9 gene could be unrelated strains. In addition, results show that cry9-positive isolates may be heterogenous because Rivera \& Priest (2003) have reported that serovars canadensis and entomocidus exhibited unique patterns and were described as heterogenous. Similar to their results, our findings also showed that there is no exact correlation between cry gene content and PFGE patterns. This is possible because cry genes are often carried on plasmids and plasmid exchange between strains as well as recombination between cry genes from different backgrounds occur in Bt strains (De Maagd et al. 2001). As a result, extensive genetic characterization and PFGE patterns will give more definite results about diversity of Bt strains with different cry genes.

In conclusion, this study is the first for isolation and characterization of Bt native strains in Turkey. Different PFGE patterns of isolates carrying the same cry gene indicates wide range of biodiversity among Bt strains in Anatolia. Planned further studies related to Bt isolation from different parts of Anatolia and detailed genetic characterization as well as toxic activity will give more comprehensive results about biodiversity of $\mathrm{Bt}$ strains.

\section{Acknowledgements}

This work was partially supported by grants from IYTE (2002 IYTE43) and from DPT (2002K-1207390).

\section{References}

Aronson, A. 2002 Sporulation and $\delta$-endotoxin synthesis by Bacillus thuringiensis. Cellular and Molecular Life Sciences 59, 417-425.

Agaisse, H. \& Lereclus, D. 1995 How does Bacillus thuringiensis produce so much insecticidal crystal protein? Journal of Bacteriology 177, 6027-6032.

Bel, Y., Granero, F., Alberola, T.M., Martinez-Sebastian, M.J. \& Ferre, J. 1997 Distribution, frequency and diversity of Bacillus thuringiensis in olive tree environments in Spain. Systematic Applied Microbiology 20, 652-658.

Ben-Dov, E., Zaritsky, A., Dahan, E., Barak, Z., Sinal, R., Manasherob, R., Khamraev, A., Troitskaya, E., Dubitsky, A., Berezina, N. \& Margalith, Y. 1997 Extended screening by TAB;PCR for seven cry-group genes from field-collected strains of Bacillus thuringiensis. Applied and Environmental Microbiology 63, 4883-4890.

Ben-Dov, E., Wang, Q., Zaritsky, A., Manasherob, R., Barak, Z., Schneider, B., Khamraev, A., Baizhanov, M., Glupov, V. \& Margalith, Y. 1999 Multiplex PCR screening to detect cry9 genes in Bacillus thuringiensis strains. Applied and Environmental Microbiology 65, 3714-3716.

Bernhard, K., Jarrett, P., Meadows, M., Butt, J., Ellis, J., Roberts, G.M., Pauli, S., Rodgers, P. \& Burges, H.D. 1997 Natural isolates of Bacillus thuringiensis: worldwide distribution, characterization and activity against insect pests. Journal of Invertebrate Pathology 70, 59-68. 
Bravo, A., Sarabia, S., Lopez, L., Ontiveros, H., Abarca, C., Ortiz, A., Ortiz, M., Lina, L., Villalobos, V., Pena, G., Nunez-Valdez, M., Soberon, M. \& Quintero, R. 1998 Characterization of cry genes in a Mexican Bacillus thuringiensis strain collection. Applied and Environmental Microbiology 64, 4965-4972.

Bygraves, J. \& Maiden, M.C. 1992 Analysis of the clonal relationships between strains of Neisseria meningitidis by pulsed field gel electrophoresis. Journal of Genomic Microbiology 138, 523-531.

Carson, C.R., Johenson, T., Lecadet, M.-M. \& Kolstø, A.-B. 1996 Genomic organization of the entomopathogenic bacterium Bacillus thuringiensis subsp. berliner 1715. Microbiology 142, 1625-1634.

Cannon, R.J.C. 1993 Prospects and progress for Bacillus thuringiensisbased pesticides. Pesticide Science 37, 331-335.

Chak, K.F., Chao, D.C., Tseng, M.Y., Kao, S.S., Tuan, S.J. \& Feng, T.Y. 1994 Determination and distribution of cry-type genes of Bacillus thuringiensis isolates from Taiwan. Applied and Environmental Microbiology 60, 2415-2420.

Crickmore, N., Zeigler, D.R., Feitelson, J., Schnepf, E., Van-Rie, J., Lereclus, D., Baum, J. \& Dean, D.H. 1998 Revision of nomenclature for the Bacillus thuringiensis pesticidal crystal proteins. Microbiology and Molecular Biology Review 62, 807-813.

De Maagd, R.A., Bravo, A. \& Crickmore, N. 2001 How Bacillus thuringiensis has evolved specific toxins to colonize the insect world. Trends in Genetics 17, 193-199.

Edwards, D.L., Payne, J. \& Soares, G.G. 1988 Novel isolates of Bacillus thuringiensis having activity against nematodes. European Patent Application, EP 0303426 A2.

Forsyth, G. \& Logan, N.A. 2000 Isolation of Bacillus thuringiensis from Northern Victoria Land, Antarctica. Letters in Applied Microbiology 30, 263-266.

Feitelson, J.S., Payne, J. \& Kim, L. 1992 Bacillus thuringiensis: insects and beyond. Bio/Technology 10, 271-275.

Gonzales, J.M. \& Carlton, B.C. 1980 Patterns of plasmid DNA in crystalliferous strains of B. thuringiensis. Plasmid 3, 92-98.

Hongyu, Z., Ziniu, Y. \& Wangxi, D. 2000 Isolation, distribution and toxicity of Bacillus thuringiensis from warehouses in China. Crop Protection 19, 449-454.

Iriarte, J., Porcar, M., Lecadet, M.M. \& Caballero, P. 2000 Isolation and characterization of Bacillus thuringiensis strains from aquatic environments in Spain. Current Microbiology 40, 402-408.

Juarez-Perez, V.M., Ferrandis, M.D. \& Frutos R. 1997. PCR-based approach for detection of novel Bacillus thuringiensis cry genes. Applied and Environmental Microbiology 63, 2997-3002.

Maeda, M., Mizuki, E., Nakamura, Y., Hatano, T. \& Ohba, M. 2000 Recovery of Bacillus thuringiensis from marine sediments of Japan. Current Microbiology 40, 413-422.

Martin, P.A.W. \& Travers, R.S. 1989 Worldwide abundance and distribution of Bacillus thuringiensis isolates. Applied and Environmental Microbiology 55, 2437-2442.

Meadows, M.P., Ellis, D.J., Butt, J., Jarrett, P. \& Burges, D. 1992 Distribution, frequency and diversity of Bacillus thuringiensis in an animal feed mill. Applied and Environmental Microbiology 58, $1344-1350$.

Mizuki, E., Ichimatsu, T., Hwang, S.H., Park, Y.S., Saitoh, H., Higuchi, K. \& Ohba, M. 1999 Ubiquity of Bacillus thuringiensis on phylloplanes of arboreous and herbaceous plants in Japan. Journal of Applied Microbiology 86, 979-984.

Ohba, M., \& Aizawa, K. 1986 Distribution of Bacillus thuringiensis in soils of Japan. Journal of Invertebrate Pathology 47, 277-282.

O'Sullivan, D.J. \& Klaenhammer, T.R. 1993 Rapid mini-prep. isolation of high-quality plasmid DNA from Lactococcus and Lactobacillus spp. Applied and Environmental Microbiology 59, 2730-2733.

Porcar, M. \& Juarez-Perez, V. 2002 PCR-based identification of Bacillus thuringiensis pesticidal crystal genes. FEMS Microbiology Reviews 757, 1-4.

Rivera, A.M.G. \& Priest, F.G. 2003 Pulsed field gel electrophoresis of chromosomal DNA reveals a clonal population structure to Bacillus thuringiensis that relates in general to crystal protein gene content. FEMS Microbiology Letters 223, 61-66.

Rowe, G.E., Margaritis, A. \& Dulmage H.T. 1987 Bioprocess developments in the production of bioinsecticides by Bacillus thuringiensis. Critical Reviews in Biotechnology 6, 87-127.

Schnepf, E., Crickmore, N., Van-Rie, J., Lereclus, D., Baum, J., Feitelson, J., Zeigler, D.R. \& Dean, D.H. 1998 Bacillus thuringiensis and its insecticidal proteins. Microbiology and Molecular Biology Reviews 62, 774-806.

Shisa, N., Wasano, N. \& Ohba, M. 2002 Discrepancy between cry gene-predicted and bioassay-determined insecticidal activities in Bacillus thuringiensis natural isolates. Journal of Invertebrate Pathology 81, 59-61.

Tenover, F.C., Arbeit, R.D., Goering, R.V., Mickelson, P.A., Murray, B.E., Persing, D.H. \& Swaminathan, B.A. 1995 Interpreting chromosomal DNA restriction patterns produced by pulse-field gel electrophoresis: criteria for bacterial typing. Journal of Clinical Microbiology 33, 2233-2239.

Theunis, W., Aguda, R.M., Cruz, W.T., Decock, C., Peferoen, M., Lambert, B., Bottrell, D.G., Gould, F.L., Litsinger, J.A. \& Cohen, M.B. 1998 Bacillus thuringiensis isolates from the Philippines: habitat distribution, $\delta$-endotoxin diversity and toxicity to rice stem borers (Lepidoptera: Pyralidae). Bulletin of Entomological Research 88, 335-342.

Thomas, D.J.I., Morgan, A.W., Whipps, J.M. \& Saunders, J.R. 2001 Plasmid transfer between Bacillus thuringiensis subsp. israelensis strains in laboratory culture, river water and dipteran larvae. Applied and Environmental Microbiology 67, 330-338.

Travers, R.S., Martin, P.A.W. \& Reichelderfer, C.F. 1987. Selective process for efficient isolation of soil Bacillus spp. Applied and Environmental Microbiology 53, 1263-1266.

Uribe, D., Martinez, W. \& Ceron, J. 2003 Distribution and diversity of cry genes in native strains of Bacillus thuringiensis obtained from different ecosystems from Colombia. Journal of Invertebrate Pathology 82, 119-127. 